\title{
Educational technologies on sexually transmitted infections for incarcerated women
}

\author{
Isaiane da Silva Carvalho ${ }^{1}$ \\ (iD) https://orcid.org/0000-0002-8478-2032 \\ Tatiane Gomes Guedes ${ }^{1}$ \\ (iD) https://orcid.org/0000-0001-7149-2290 \\ Simone Maria Muniz da Silva Bezerra² \\ (1) https://orcid.org/0000-0002-0974-1409 \\ Fábia Alexandra Pottes Alves ${ }^{3}$ \\ (D) https://orcid.org/0000-0002-2478-5346 \\ Luciana Pedrosa Leal ${ }^{1}$ \\ (iD) https://orcid.org/0000-0003-3776-0997 \\ Francisca Márcia Pereira Linhares ${ }^{1}$ \\ (D) https://orcid.org/0000-0001-9778-5024
}

\footnotetext{
1 Universidade Federal de Pernambuco, Recife, PE, Brazil.

2 Universidade de Pernambuco, Faculdade de Enfermagem Nossa Senhora das Graças, Recife, PE, Brazil.

3 Universidade Federal de Pernambuco, Departamento de Enfermagem, Recife, PE, Brazil.
}

Objective: to analyze in the scientific literature the educational technologies on sexually transmitted infections used in health education for incarcerated women. Method: an integrative review carried out by searching for articles in the following databases: Scopus, Cumulative Index of Nursing and Allied Health, Education Resources Information Center, PsycInFO, Medical Literature Analysis and Retrieval System Online, Latin American Literature in Health Sciences, Cochrane, and the ScienceDirect electronic library. There were no language and time restrictions. A search strategy was developed in PubMed and later adapted to the other databases. Results: a total of 823 studies were initially identified and, after applying inclusion and exclusion criteria, eight articles were selected. Most of them were developed in the United States with a predominance of randomized clinical trials. The technologies identified were of the printed materials type, isolated or associated to simulators of genital organs, videos, and games. Conclusion: the technologies on sexually transmitted infections used in health education for incarcerated women may contribute to adherence to the prevention of this serious public health problem in the context of deprivation of liberty.

Descriptors: Educational Technology; Sexually Transmitted Diseases; Sex Education; Health Education; Women; Prisons.

\section{How to cite this article}

Carvalho IS, Guedes TG, Bezerra SMMS, Alves FAP, Leal LP, Linhares FMP. Educational technologies on sexually transmitted infections for incarcerated women. Rev. Latino-Am. Enfermagem. 2020;28:e3392. [Access ]; Available in: DOI: http://dx.doi.org/ 10.1590/1518-8345.4365.3392. 


\section{Introduction}

Sexually Transmitted Infections (STIs) are associated with more than 30 microorganisms. Of the eight most incident STIs, four are curable, namely: syphilis, gonorrhea, chlamydia, and trichomoniasis. However, hepatitis $B$, herpes, human immunodeficiency virus (HIV), and human papilloma virus (HPV) remain incurable despite the existence of treatment(1).

Worldwide, more than 1 million curable STIs occur every day. In this sense, the prevention and control of these infections happen as an excellent strategy in the field of public health. In 2016, the World Health Organization launched a global initiative to reduce STIs (2016-2021). Among its principles are universal health coverage, use of evidence-based interventions, promotion of human rights with gender equality and equity in health, and empowerment of the most affected by STIs ${ }^{(2)}$.

Incarcerated women are in this group, having the STI problem enhanced during their deprivation of liberty ${ }^{(3)}$. These women are more likely to be infected with an STI when compared to the general population ${ }^{(4-6)}$. In addition, incarcerated individuals have a history of risky behavior in prison, such as sharing needles and unprotected sex, which favor the occurrence of this type of infection ${ }^{(7-8)}$. Among the STIs most associated with this population are HIV, syphilis, genital herpes, viral hepatitis, gonorrhea, chlamydia, and HPV(9-15).

The Bangkok rules, an international document on the treatment of incarcerated women, state that they should receive education and information on how to prevent STIs ${ }^{(16)}$. Sometimes coming from less favored segments of society, these women have little knowledge about STI prevention(17-18). This raises the need to develop health education actions with a focus on minimizing the number of cases.

Educational technologies come as a health education strategy to be considered in the teachinglearning process. These tools can, for example, stimulate lifestyle changes in the individual field, contribute to the control of risk factors considered modifiable, and favor adherence to treatments ${ }^{(19)}$.

The acquisition of new knowledge may not guarantee changes in behavior; however, in many situations, lack of knowledge can lead to inappropriate self-care behaviors. Thus, when shared among people in a concrete way, the information based on solid evidence may be able to produce changes in lifestyle regarding self-care practices in the prevention of STIs ${ }^{(20)}$.

It is highlighted that, until now, no review studies on the use of educational technologies on STIs for incarcerated women have been identified in the national and international literature. Thus, this research can contribute to fill this gap. Likewise, its results can subsidize the practice of health professionals by allowing decision-making based on scientific evidence and, at the same time, by promoting critical reflections related to the use of technologies on STIs in the perspective of health education in this population. This study aimed to analyze in the scientific literature the educational technologies on STIs used in health education for incarcerated women.

\section{Method}

An integrative review developed based on the following stages: formulation of the problem; literature search; data evaluation; data analysis; and presentation of the results(21). As a way of assisting data collection, we proceeded with the elaboration of a search protocol, which contained the following information: theme; objective; guiding question; search strategies (database, descriptors, and intersections); inclusion and exclusion criteria; and data collection procedure.

The research question was elaborated based on the PICo strategy: (P) - Population (incarcerated women); (I) - Interest (educational technology on STIs); (Co) - Context (health education) ${ }^{(22)}$. Thus, the following question was obtained: What are the evidences available in the literature related to educational technologies on STIs used in health education for incarcerated women?

The selected databases were Scopus, Cumulative Index of Nursing and Allied Health (CINAHL), Education Resources Information Center (ERIC), PsycInFO; MEDLINE (via PubMed), Latin American Literature in Health Sciences (Literatura Latino-Americana em Ciências da Saúde, LILACS), and Cochrane, in addition to the ScienceDirect electronic library. The selection of articles took place in January 2020. For that, MeSH controlled descriptors and their synonyms were used. An asterisk was added to the descriptors to retrieve studies that presented words stemming from the same radical. The descriptors were combined using the Boolean operators "AND" and "OR". Articles indexed with MeSH terms were selected, as well as their presence or their synonyms in the title/abstract. Initially, the search strategy was developed in PubMed and was later adapted for the other databases and electronic library (Figure 1). 


\begin{tabular}{|c|c|c|}
\hline \multicolumn{3}{|c|}{ PICo strategy* } \\
\hline \multirow[b]{2}{*}{ P (Population) } & \multirow[b]{2}{*}{ Incarcerated women } & List of descriptors \\
\hline & & $\begin{array}{l}\text { Women }[\mathrm{MH}] \\
\text { Woman }[\mathrm{TIAB}] \\
\text { Girl* }[\mathrm{TIAB}] \\
\text { Female }[\mathrm{MH}] \\
\text { Female* }[\mathrm{TIAB}] \\
\text { Prisons }[\mathrm{MH}] \\
\text { Prison* }[\mathrm{TIAB}] \\
\text { Incarceration }[\mathrm{TIAB}]\end{array}$ \\
\hline I (Interest) & Educational technology on STIs ${ }^{\dagger}$ & $\begin{array}{l}\text { Educational Technology [MH] } \\
\text { Educational Technolog* }[\text { TIAB] } \\
\text { Instructional Technolog* }[\text { TIAB] } \\
\text { Sexually Transmitted Diseases [MH] } \\
\text { Sexually Transmitted Diseases [TIAB] } \\
\text { STIs [TIAB] } \\
\text { Venereal Diseas* [TIAB] } \\
\text { Sexually Transmitted Infections }[\mathrm{MH}] \\
\text { Sexually Transmitted Infection* }[\text { TIAB] } \\
\text { STDs [TIAB] }\end{array}$ \\
\hline Co (Context) & Health education & $\begin{array}{l}\text { Health Education }[\mathrm{MH}] \\
\text { Health Education }[\mathrm{TIAB}] \\
\text { Health Promotion }[\mathrm{MH}] \\
\text { Health Promotion }[\mathrm{TIAB}] \\
\text { Community Health Education }[\mathrm{TIAB}] \\
\text { Sex Education }[\mathrm{MH}] \\
\text { Sex Education }[\mathrm{TIAB}]\end{array}$ \\
\hline \multicolumn{3}{|c|}{ Search strategy in PubMed } \\
\hline $\begin{array}{l}\text { 1. Women[MeS } \\
\text { Terms] OR Pris } \\
\text { 2. Educational } \\
\text { Transmitted Dis } \\
\text { OR Sexually Tr } \\
\text { 3. Health Educe } \\
\text { Community Hea } \\
\text { 4. \#1 AND \#2 A }\end{array}$ & $\begin{array}{l}\text { s] OR Woman[Title/Abstract] OR Girl* } \\
\text { /Abstract] OR Incarceration[Title/Abst } \\
\text { gy[MeSH Terms] OR Educational Tec } \\
\text { MeSH Terms] OR Sexually Transmitte } \\
\text { SH Tections[MeSH Terms] OR Sexua } \\
\text { cation[Title/Abstract] OR Sex Educati }\end{array}$ & $\begin{array}{l}\text { OR Female[MeSH Terms] OR Female*[Title/Abstract] AND Prisons[MeSH } \\
\text { Abstract] OR Instructional Technolog*[Title/Abstract] AND Sexually } \\
\text { le/Abstract] OR STIs[Title/Abstract] OR Venereal Diseas*[Title/Abstract] } \\
\text { Infection*[Title/Abstract] OR STDs[Title/Abstract] } \\
\text { Health Promotion[MeSH Terms] OR Health Promotion[Title/Abstract] OR } \\
\text { ns] OR Sex Education[Title/Abstract] }\end{array}$ \\
\hline
\end{tabular}

*PICo $=$ Population, interest, and context; ${ }^{+}$STIs = Sexually transmitted infections

Figure 1 - PICo strategy and descriptors used. Recife, PE, Brazil, 2020

The adopted inclusion criteria were the following: original articles that addressed the use of educational technology for incarcerated women, published until 2019 in any language and available electronically in full. Articles that did not answer the research question were excluded.

The databases were accessed through the journal portal of the Coordination for the Improvement of Higher Level Personnel, via institutional remote access. This procedure was adopted to expand the search for articles in their entirety. For data extraction, a script was prepared in Excel containing the following information: author, title, year of publication, country, language, journal, objective, study design, number of participants, type of technology, type of STI, outcome, and level of evidence.

For the classification of the level of evidence, the following division was adopted: $1 \mathrm{~A}$ - Systematic review of randomized controlled clinical trials; $1 \mathrm{~B}$ - Randomized controlled clinical trial with a narrow confidence interval; 1 - Therapeutic results of the "all or nothing" type; 2A - Systematic review of cohort studies; 2B - Cohort study (including randomized clinical trial of lesser quality); 2C - Observation of therapeutic results and ecological study; 3A - Systematic review of casecontrol studies; 3B - Case-control study; 4 - Case report (including lower quality cohort or case-control); and 5 - Expert opinion(23).

The articles were exported to the EndNote online program to remove duplicate studies. Then, the titles and abstracts of the articles were examined in EndNote itself and those that met the selection criteria were considered for the next phase. These were organized according to the selection database/library, in an Excel spreadsheet. Subsequently, the article was read in full. The selection was carried out independently by two researchers, and the differences were solved by consensus. 
Data analysis was performed in a descriptive manner with the results presented in a summary table and discussed based on the available literature on the subject. As the study did not involve research with human beings, there was no need for submission to the Research Ethics Committee. However, it is highlighted that the authors' original ideas were maintained when proceeding with the synthesis of the results. The Preferred Reporting Items for Systematic Reviews and Meta-Analyses (PRISMA)(24) recommendations were adopted for drafting the manuscript.

\section{Results}

A total of 823 articles were identified and eight were selected after applying the inclusion and exclusion criteria, as shown in Figure 2.

Of the eight studies that were included in the integrative review, five were identified in MEDLINE(25-29), one in Cochrane ${ }^{(30)}$, one in ScienceDirect ${ }^{(31)}$, and one in CINAHL (32). Most of the studies were developed in the United States $(7)^{(25-30,32)}$ and all of them were written in English. Only one article was prepared in Brazil(31). Publications between 1997 and 2018 were identified, with a predominance of 2015, which presented four publications ${ }^{(26,30-32)}$. Each article was published in a different journal. Only two articles were published in journals linked to the areas of behavioral and social sciences $^{(31)}$ and interpersonal violence ${ }^{(32)}$. The others were associated with the health area. As for the type of study, five were randomized clinical trials(25-26,30-32) and three were descriptive studies(26,31-32).

The educational technologies used on STIs for incarcerated women were printed materials with two interventions with this type of material associated with genital organ simulators ${ }^{(31-32)}$, followed by video(28-30) and games ${ }^{(27)}$. It should be noted that the educational technologies described were not used in isolation, but as part of an educational intervention that involved, for example, $\operatorname{group}^{(26,29,31)}$ sessions or combinations of group and individual sessions ${ }^{(25,32)}$. Regarding the types of STIs, HIV was the object of two technologies ${ }^{(26,28)}$ and one study addressed HIV and the Hepatitis C virus ${ }^{(25)}$. The other studies addressed STIs/HIV(27,29-32). As for the level of evidence, one randomized clinical trial was classified as $1 \mathrm{~B}^{(28)}$, and four as $2 \mathrm{~B}^{(25,27,29-30)}$. The other studies were classified as having a level of evidence of $4^{(26,31-32)}$. A chart was created to summarize the main characteristics of the studies (Figure 3 ).

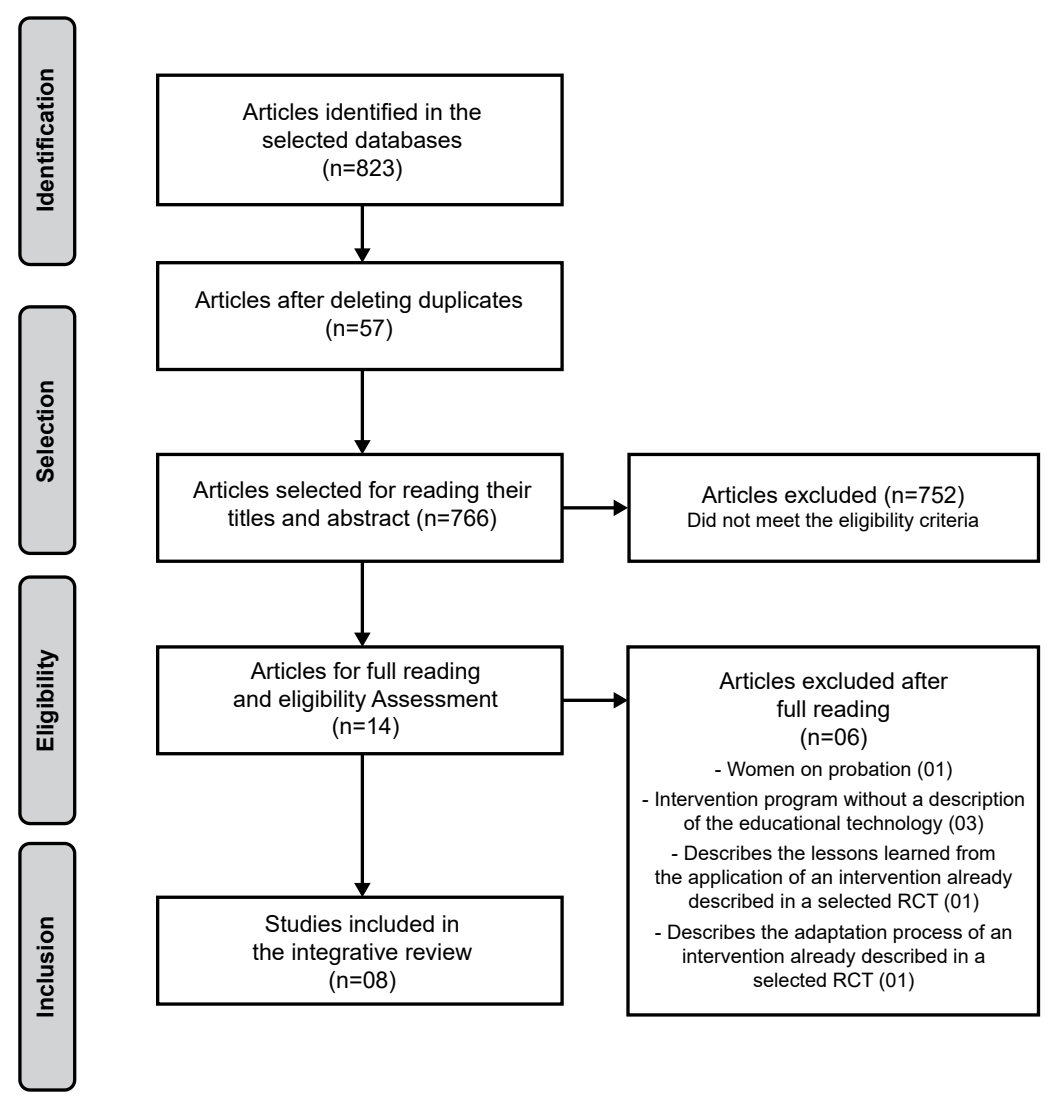




\begin{tabular}{|c|c|c|c|c|}
\hline $\begin{array}{l}\text { Authors, year of } \\
\text { publication and country }\end{array}$ & Objective & $\begin{array}{l}\text { Type of study and } \\
\text { No. of participants }\end{array}$ & $\begin{array}{l}\text { Educational } \\
\text { technology }\end{array}$ & Evidence level \\
\hline $\begin{array}{l}\text { Staton, et al., } 2018^{(25)} \\
\text { United States }\end{array}$ & $\begin{array}{l}\text { To evaluate a standard educational intervention and an } \\
\text { improved individualized intervention (standard educational } \\
\text { intervention + motivational interview) to reduce the risk of } \mathrm{HIV}^{*} \\
\text { in women who use drugs in rural prisons. }\end{array}$ & $\begin{array}{l}\text { Randomized clinical } \\
\text { trial } \\
\mathrm{n}=400\end{array}$ & $\begin{array}{l}\text { Printed material } \\
\text { (cards) }\end{array}$ & $2 \mathrm{~B}$ \\
\hline $\begin{array}{l}\text { Fogel, et al., } 2015^{(30)} \\
\text { United States }\end{array}$ & $\begin{array}{l}\text { To test the effectiveness of an adapted, evidence-based } \\
\text { behavioral intervention for the prevention of } \mathrm{HIV}^{*} / \mathrm{STDs}^{\dagger} \\
\text { among incarcerated women. }\end{array}$ & $\begin{array}{l}\text { Randomized clinical } \\
\text { trial } \\
\mathrm{n}=521\end{array}$ & Video & $2 B$ \\
\hline $\begin{array}{l}\text { Guedes, et al., } 2015^{(31)} \\
\text { Brazil }\end{array}$ & $\begin{array}{l}\text { To carry out educational actions focused on preventing the } \\
\text { transmission of sexual diseases/human immunodeficiency } \\
\text { virus, safe sexual practices, family planning, violence, and } \\
\text { prevention of uterine and breast cancer. }\end{array}$ & $\begin{array}{l}\text { Descriptive study } \\
n=\text { not informed }\end{array}$ & $\begin{array}{l}\text { Printed material } \\
\text { (photos and } \\
\text { pictures) }+ \\
\text { simulators of } \\
\text { genital organs }\end{array}$ & 4 \\
\hline $\begin{array}{l}\text { Gupta, et al., } 2015^{(26)} \\
\text { United States }\end{array}$ & $\begin{array}{l}\text { To describe the program, the baseline, and the characteristics } \\
\text { of the participating women; and to present the results of } \\
\text { the evaluation of the program called Tudo sobre profilaxia } \\
\text { pós-exposição não ocupacional (Everything about non- } \\
\text { occupational post-exposure prophylaxis). }\end{array}$ & $\begin{array}{l}\text { Descriptive study } \\
\mathrm{n}=114\end{array}$ & $\begin{array}{l}\text { Printed material } \\
\text { (folder) }\end{array}$ & 4 \\
\hline $\begin{array}{l}\text { Johnson, et al., 2015(32) } \\
\text { United States }\end{array}$ & $\begin{array}{l}\text { To report the justification for the intervention, feasibility, } \\
\text { acceptability, and pre-post results in a small initial feasibility } \\
\text { study conducted with } 14 \text { women who received the intervention } \\
\text { before release from prison, with follow-up assessments at } 2,5 \text {, } \\
\text { and } 8 \text { months after release. }\end{array}$ & $\begin{array}{l}\text { Descriptive study } \\
n=14\end{array}$ & $\begin{array}{l}\text { Printed material } \\
\text { (safe sex } \\
\text { booklet) }+ \\
\text { simulators of } \\
\text { genital organs }\end{array}$ & 4 \\
\hline $\begin{array}{l}\text { DiClemente, et al., } \\
2014^{(27)} \\
\text { United States }\end{array}$ & $\begin{array}{l}\text { To assess the effectiveness of an intervention to reduce } \mathrm{STD}^{\dagger} \\
\text { incidents, improve HIV preventive behaviors, and improve the } \\
\text { psychosocial outcomes. }\end{array}$ & $\begin{array}{l}\text { Randomized clinical } \\
\text { trial } \\
\mathrm{n}=188\end{array}$ & $\begin{array}{l}\text { Interactive } \\
\text { computer } \\
\text { games }\end{array}$ & $2 B$ \\
\hline $\begin{array}{l}\text { Knudsen, et al., 2014(28) } \\
\text { United States }\end{array}$ & 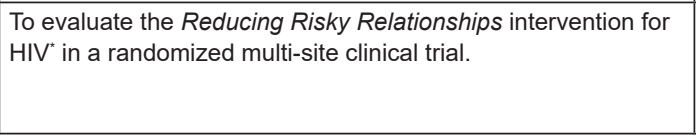 & $\begin{array}{l}\text { Randomized clinical } \\
\text { trial } \\
\mathrm{n}=444\end{array}$ & Video & $1 \mathrm{~B}$ \\
\hline $\begin{array}{l}\text { Lawrence, et al., } 1997^{(29)} \\
\text { United States }\end{array}$ & $\begin{array}{l}\text { To compare an intervention based on the social cognitive } \\
\text { theory with a comparison condition based on the gender } \\
\text { theory and the power in reducing the risk of } \mathrm{HIV}^{*} \text { in } \\
\text { incarcerated women. }\end{array}$ & $\begin{array}{l}\text { Randomized clinical } \\
\text { trial } \\
\mathrm{n}=90\end{array}$ & Video & $2 \mathrm{~B}$ \\
\hline
\end{tabular}

${ }^{*}$ HIV = Human immunodeficiency virus; ${ }^{+}$STDs = Sexually transmitted diseases

Figure 3 - Presentation of the articles included in the review. Recife, PE, Brazil, 2020

\section{Discussion}

The technologies identified in this review used in health education about STIs for incarcerated women were printed materials, used alone or associated with simulators of genital organs, videos, and games. The absence of other types of technologies, especially the ones that use the Internet, can be a consequence of the difficulties of their insertion in the context of incarceration due to institutional security issues. This condition represents a challenge for the researchers in the area and, at the same time, encourages the development of alternative strategies to the limitations imposed by the deprivation of liberty scenario.

Regarding the period in which the studies were published, there is little expression of the use of this type of educational resource in the $20^{\text {th }}$ century ${ }^{(29)}$. On the other hand, since 2014 there has been a significant increase in the description in scientific studies of the use of technologies in the health education process related to the STIs for women deprived of their liberty (25-28,30-32). This may reflect the growing number of studies aimed at building technologies developed to improve the health care and education process. In this sense, in view of the magnitude of the STI problem in the prison context, it is expected that in the coming years new technologies can be produced to assist the activities developed by the professionals in these areas and their effect assessed through robust studies.

In addition, the period of conducting new studies corresponds to the period of increase in the number of women incarcerated in the world. There has been a growth of more than $50 \%$ of women deprived of their liberty worldwide since 2000, with values that exceed $700,000^{(33)}$. Added to this are the changes produced in the field of health education and teaching with the insertion of new technologies.

However, the use of digital technologies or equipment does not correspond to an innovation in teaching from a methodological point of view. When applied in the field of education, these resources can be an aid tool in the teaching and learning process. It is necessary that the purposes for their use are clear. In addition, the use of educational technologies requires adaptations for those involved in this process, including the environment( ${ }^{(34)}$.

The fact that the majority of the studies have been carried out in the United States shows the importance 
given by the scientific community to the problem of STIs for incarcerated American women. At the same time, it reflects the extent of the problem, since the United States is the country with the largest population of women deprived of their liberty in the world, with more than $200,000^{(33)}$.

The health demands of this population are complex, which is enhanced by the low visibility in the USA public policies. As a consequence, fewer resources are allocated when compared to the male prison population, which results in the inability of the prison institutions to respond to the women's health needs ${ }^{(35)}$. This reality is aggravated when considering the panorama of underdeveloped countries that face numerous problems in sensitive social sectors such as health, education, and security, and which have to deal with a limited amount of financial resources.

Regarding the language, it is understandable that, as English is the main language used by the scientific community to disseminate research studies $^{(36)}$, it has had an absolute presence. STIs are considered a serious public health problem $^{(1)}$ and this explains the fact that the studies have been published especially in health journals. However, this is a problem that, when associated with incarceration, can be dealt in a crosssectional manner, which justifies the presence of articles published in other areas of knowledge $\mathrm{e}^{(31-32)}$.

The research studies of the randomized clinical trial type were the main study designs adopted by the authors and showed that the interventions performed were tested following a method capable of producing robust evidence. The results from studies of this nature represent one of the best evidence available in the scientific community, given the rigor with which they are conducted( ${ }^{(37)}$. This reflects the high level of evidence obtained by most of the studies, although among the clinical trials, only 1 has obtained level $1 \mathrm{~B}$. This occurred due to the follow-up losses greater than $20 \%$ present in the other trials, which makes them be classified as $2 \mathrm{~B}^{(23)}$.

The interventions in which the technologies described above were used varied as to the manner of employment, making evident a broader process that involved group and individual sessions(25-26,29,31-32) and in, some cases, even follow-up after freedom was granted ${ }^{(27-28,30)}$. This reinforces the concept that technology is another tool to assist the professionals in the health education process and that the results obtained cannot be attributed exclusively to their employment, but to the intervention as a whole.

Regarding the STIs, there was a strong presence of HIV/AIDS. The prevalence of HIV in prisons is higher than in the community ${ }^{(38)}$. In this sense, fighting HIV infection in prison settings represents an enormous challenge for both the health and the judiciary system. In addition, it is necessary to consider the repercussions that HIV infection can cause in both the individual and collective fields. Likewise, the costs associated with prevention are notably lower than those spent on treatments(39).

The printed material was frequently used as educational technology in the studies analyzed, sometimes associated with other technologies or strategies, such as simulators of genital organs ${ }^{(31-32)}$. It is known that the prison setting has limitations regarding the entry of technological resources, even if educational. Digital technologies or those that need access to the Internet are hardly used in this setting. This is related to the choice of printed materials, such as folders, pictures, photos, and booklets ${ }^{(31-32)}$.

Other resources such as videos and games were also used(27-30). These technologies can be built and used to boost the teaching and learning process without the need for Internet access, which favors their use in prison settings.

Videos are educational technologies that can be used in health education, either in isolation or in association with other technologies ${ }^{(40)}$. In the context of the STIs, brief interventions based on videos can be considered economical tools in the prevention of new cases, especially in places where the time of the health professionals is limited or where prevention programs with a longer duration are not available(41).

As for the use of games, these allow the student to memorize information, stimulate learning and greater involvement, conditions that favor its use at different moments in the teaching-learning process ${ }^{(42)}$. The game can be used as a prevention and continuous care strategy for specific diseases, such as HIV. Thus, by means of an interactive and dynamic approach, important behavioral changes related to health can be achieved(43).

Regardless of the technology to be used, it is important to consider active methods in the health education process and to understand that their use is more than the simple insertion of a technological resource ${ }^{(44)}$. A systematic review with meta-analysis showed that active learning methods promoted better performance of underrepresented students (ethnic, racial, and low-income minorities) in science, technology, engineering, and mathematics courses when compared to traditional classes ${ }^{(45)}$.

Finally, most of the studies have highlighted the importance of these interventions as a viable strategy for reducing risky behaviors and for the consequent STI prevention in incarcerated women. Such results can provide subsidies for nurses and other health professionals with regard to the development of new 
technologies and educational programs associated with STIs in the female prison context.

As a limitation, there is the fact that most of the studies correspond to the North American reality, which presents particularities regarding the profile of the population of incarcerated women, the health system, and justice.

\section{Conclusion}

This review concluded that the educational technologies on sexually transmitted infections most used for incarcerated women were printed materials, either isolated or associated with simulators of genital organs, videos, and games. These technologies were described with a predominance of the approach on HIV/ AIDS, mainly in studies such as randomized clinical trials, which confirms the importance of this problem among the infections that affect incarcerated women. Thus, the use of these technologies from the perspective of health education may contribute to the prevention of this serious public health problem in the context of deprivation of liberty.

In terms of knowledge gaps, it was observed that some studies did not describe the validation process of the educational technologies or programs used. In addition, the lack of studies in other parts of the world compromises the generalization of the results and, when present, the short follow-up time makes it difficult to measure the impact of the intervention in the long term.

New studies need to be developed to assess the effect of these technologies, especially in other countries, such as Brazil. Likewise, other technologies on STIs prevalent in this population need to be produced, taking into account a solid validation process and the particularities present in the prison system.

\section{References}

1. World Health Organization. Sexually transmitted infections (STIs). [Internet]. 2019 [cited Jan 6, 2020]. Available from: https://www.who.int/news-room/factsheets/detail/sexually-transmitted-infections-(stis)

2. World Health Organization. Report on global sexually transmitted infection surveillance. [Internet]. Geneva: WHO; 2018. [cited Feb 12, 2020]. Available from: https://www.who.int/reproductivehealth/publications/ stis-surveillance-2018/en/

3. Emerson AM, Carroll HF, Ramaswamy M. Education level as a predictor of condom use in jail-incarcerated women, with fundamental-cause analysis. Public Health Nurs. [Internet]. 2018 [cited July 14, 2019];35(4):27380. Available from: http://dx.doi.org/10.1111/phn.12514
4. Maruschak IM, Berzofsky M, Unangst J. Medical Problems of State and Federal Prisoners and Jail Inmates, 2011-12. [Internet]. Washington, D.C: Bureau of Justice Statistics; 2016 [cited Oct 14, 2019]. Available from: https://www.bjs.gov/content/pub/pdf/mpsfpji1112.pdf 5. Besney JD, Angel C, Pyne D, Martell R, Keenan L, Ahmed R. Addressing Women's Unmet Health Care Needs in a Canadian Remand Center: Catalyst for Improved Health? J Correct Health Care. 2018;24(3):276-94. doi: http://dx.doi.org/10.1177/1078345818780731

6. Wise A, Finlayson T, Nerlander L, Sionean C, PazBailey G; NHBS Study Group. Incarceration, Sexual Risk-Related Behaviors, and HIV Infection Among Women at Increased Risk of HIV Infection, 20 United States Cities. J Acquir Immune Defic Syndr. 2017;75 Suppl 3:S261-7. doi: http://dx.doi.org/10.1097/ QAI.0000000000001401

7. Felisberto $M$, Saretto $A A$, Wopereis $S$, Treitinger A, Machado MJ, Spada C. Prevalence of human immunodeficiency virus infection and associated risk factors among prison inmates in the City of Florianópolis. Rev Soc Bras Med Trop. 2016;49(5):620-3. doi: http:// dx.doi.org/10.1590/0037-8682-0187-2016

8. Pala KC, Baggio S, Tran NT, Girardin F, Wolff H, Gétaz L. Blood-borne and sexually transmitted infections: a cross-sectional study in a Swiss prison. BMC Infect Dis. 2018;18(1):539. doi: http://dx.doi.org/10.1186/ s12879-018-3445-6

9. Adams JW, Lurie MN, King MRF, Brady KA, Galea S, Friedman $S R$, et al. Potential drivers of HIV acquisition in African-American women related to mass incarceration: an agent-based modelling study. BMC Public Health. 2018;18(1):1387-97. doi: http://dx.doi.org/10.1186/ s12889-018-6304-x

10. Villarroel-Torrico $M$, Montaño $K$, Flores-Arispe $P$, Jeannot $E$, Flores-León $A$, Cossio $N$, et al. Syphilis, human immunodeficiency virus, herpes genital and hepatites $B$ in a women's prison in Cochabamba, Bolivia: prevalence and risk factors. Rev Esp Sanid Penit. 2018 [cited Feb 3, 2020];20(2):47-54. Available from: http://scielo. isciii.es/scielo.php?script =sci_arttext\&pid=S157506202018000200047\&lng=en\&nrm=iso\&tlng=en

11. Domingues RMSM, Leal MC, Pereira APE, Ayres B, Sánchez AR, Larouzé B. Prevalence of syphilis and HIV infection during pregnancy in incarcerated women and the incidence of congenital syphilis in births in prison in Brazil. Cad Saúde Pública. 2017;33(11):e00183616. doi: http://dx.doi.org/10.1590/0102-311×00183616

12. Burghardt NO, Chow JM, Steiner A, Bauer HM. Trends in Chlamydia Screening, Test Positivity, and Treatment Among Females in California Juvenile Detention Facilities, 2003-2014. Sex Transm Dis. 2016;43(1):12-7. doi: http://dx.doi.org/10.1097/OLQ.0000000000000382 
13. Stephens $T$, Holliday RC, Hopkins $S$, Rose $S$, Braithwaite $R$, Smith $S$. Correlates of African American female adolescent offenders 3, 4-Methylenedioxymethamphetamine (MDMA or "Ecstasy") useand sexually transmittedinfectionmorbidity. J Hum Behav Soc Environ. 2016;26(2):194-201. doi: http://dx.doi.org/ 10.1080/10911359.2015.1083502

14. Courtemanche Y, Poulin C, Serhir B, Alary M. HIV and hepatitis $C$ virus infections in Quebec's provincial detention centres: comparing prevalence and related risky behaviours between 2003 and 2014-2015. Can J Public Health. 2018;109(3):353-61. doi: http://dx.doi. org/ 10.17269/s41997-018-0047-4

15. Moore A, Cox-Martin M, Dempsey AF, Berenbaum Szanton K, Binswanger IA. HPV Vaccination in Correctional Care: Knowledge, Attitudes, and Barriers Among Incarcerated Women. J Correct Health Care. 2019;25(3):219-30. doi: http://dx.doi. org/10.1177/1078345819853286

16. Conselho Nacional de Justiça (BR). Regras de Bangkok: regras das Nações Unidas para o tratamento de mulheres presas e medidas não privativas de liberdade para mulheres infratoras. [Internet]. 2016 [Acesso 24 jun 2020]. Disponível em: https:// www.cnj.jus.br/wp-content/uploads/2019/09/ cd8bc11ffdcbc397c32eecdc40afbb74.pdf

17. Muessig KE, Rosen DL, Farel CE, White BL, Filene EJ, Wohl DA. "Inside These Fences is Our Own Little World": Prison-Based HIV Testing and HIV-Related Stigma Among Incarcerated Men and Women. AIDS Educ Prev. 2016;28(2):103-16. doi: http://dx.doi.org/10.1521/ aeap.2016.28.2.103

18. Zin NM, Ishak I, Manoharan K. Knowledge, attitude and practice towards sexually transmitted diseases amongst the inmates of women shelters homes at Klang Valley. BMC Public Health. 2019;19(Suppl 4):639. doi: https://doi.org/10.1186/s12889-019-6863-5

19. Maniva SJCF, Carvalho ZMF, Gomes RKG, Carvalho REFL, Ximenes LB, Freitas CH. Educational technologies for health education on stroke: an integrative review. Rev Bras Enferm. 2018;71(Suppl 4):1724-31. doi: https://doi.org/10.1590/0034-7167-2017-0041

20. Wild CF, Nietsche EA, Salbego C, Teixeira E, Favero NB. Validation of educational booklet: an educational technology in dengue prevention. Rev Bras Enferm. 2019;72(5):1318-25. doi: http://dx.doi. org/10.1590/0034-7167-2018-0771

21. Whittemore R, Knafl K. The integrative review: updated methodology. J Adv Nurs. 2005;52(5):546-53. doi: http://dx.doi.org/ 10.1111/j.1365-2648.2005.03621.x

22. Pollock A, Berge E. How to do a systematic review. Int J Stroke. 2018;13(2):138-56. doi: http://dx.doi.org/ $10.1177 / 1747493017743796$
23. Centre for Evidence-Based Medicine. Oxford Centre for Evidence-based Medicine - Levels of Evidence (March 2009). [Internet]. 2009 [cited Feb 15, 2020]. Available from: https://www.cebm.net/2009/06/oxford-centreevidence-based-medicine-levels-evidence-march-2009/ 24. Liberati A, Altman DG, Tetzlaff J, Mulrow C, Gøtzsche PC, Ioannidis JP, et al. The PRISMA statement for reporting systematic reviews and meta-analyses of studies that evaluate health care interventions: explanation and elaboration. PLoS Med. 2009;6(7):e1000100. doi: http://dx.doi.org/ 10.1371/journal.pmed.1000100

25. Staton M, Strickland J, Webster JM, Leukefeld C, Oser C, Pike E. HIV prevention in rural Appalachian jails: Implications for reentry risk reduction among women who use drugs. AIDS Behav. 2018; 22(12):4009-18. doi: http://dx.doi.org/ 10.1007/s10461-018-2209-z

26. Gupta N, Schmidt H, Buisker T, Dufour MS, Goldenson J, Myers J, et al. After the Fact: A Brief Educational Program on HIV Postexposure Prophylaxis for Female Detainees in a Local Jail. J Correct Health Care. 2015;21(2):14051. doi: https://doi.org/10.1177/1078345815572335

27. DiClemente RJ, Davis $T L$, Swartzendruber $A$, Fasula AM, Boyce L, Gelaude D, et al. Efficacy of an HIV/STI sexual risk-reduction intervention for African American adolescent girls in juvenile detention centers: a randomized controlled trial. Women Health. 2014;54:726-49. doi: https://doi.org/10.1080/036302 42.2014.932893

28. Knudsen HK, Staton-Tindall M, Oser CB, Havens JR, Leukefeld CG. Reducing risky relationships: a multisite randomized trial of a prison-based intervention for reducing HIV sexual risk behaviors among women with a history of drug use. AIDS Care. 2014;26(9):1071-9. doi: https://doi.org/10.1080/09540121.2013.878779

29. Lawrence J, Eldridge GD, Shelby MC, Little CE, Brasfield TL, O'Bannon RE. HIV risk reduction for incarcerated women: a comparison of brief interventions based on two theoretical models. J Consult Clin Psychol. 1997;65(3):504-9. doi: https://doi.org/10.1037//0022$006 \times .65 .3 .504$

30. Fogel CI, Crandell JL, Neevel AM, Parker SD, Carry $M$, White $B L$, et al. Efficacy of an Adapted HIV and Sexually Transmitted Infection Prevention Intervention for Incarcerated Women: A Randomized Controlled Trial. Am J Public Health. 2015;105(4):802-9. doi: http:// dx.doi.org/ 10.2105/AJPH.2014.302105

31. Guedes TG, Linhares FMP, Morais SCRV, Ferreira IF, Mendonça TG, Silva FV, et al. Health education: strategy for sexual and reproductive care for women in custody. Procedia. 2015;174:821-5. doi: https://doi. org/10.1016/j.sbspro.2015.01.668

32. Johnson JE, Peabody ME, Wechsberg WM, Rosen RK, Fernandes K, Zlotnick C. Feasibility of an HIV/STI 
Risk-Reduction Program for Incarcerated Women Who Have Experienced Interpersonal Violence. J Interpers Violence. 2015;30(18):3244-66. doi: https://doi. org/10.1177/0886260514555013

33. ICPR. World Prison Brief. World Female Imprisonment List. [Internet]. 4. ed. London: ICPR; 2017 [cited Feb 10, 2020]. Available from: https://www.prisonstudies. org/sites/default/files/resources/downloads/world_ female_prison_4th_edn_v4_web.pdf

34. Wanderley TPSP, Batista MHJ, Dutra Jr LS, Silva

VC. Docência em saúde: tempo de novas tecnologias da informação e comunicação. Rev Eletron Comun Inf Inov Saúde. 2018;12(4):488-501. doi: http://dx.doi. org/10.29397/reciis.v12i4.1522

35. Mignon, S. Health issues of incarcerated women in the United States. Ciênc Saúde Coletiva 2016;21(7):2051-9. doi: http://dx.doi.org/10.1590/141381232015217.05302016

36. Popova NG, Beavitt TA. English as a means of scientific communication: linguistic imperialism or interlingua? Integraciâ Obrazovaniâ. 2017;21(1):54-70. doi: http:// dx.doi.org/10.15507/1991-9468.086.021.201701.054070

37. Guerrera F, Renaud S, Tabbò F, Filosso PL. How to design a randomized clinical trial: tips and tricks for conduct a successful study in thoracic disease domain. J Thorac Dis. 2017;9(8):2692-6. doi: http://dx.doi. org/10.21037/jtd.2017.06.147

38. Golrokhi R, Farhoudi B, Taj L, Pahlaviani FG, Mazaheri-Tehrani E, Cossarizza A, et al. HIV Prevalence and Correlations in Prisons in Different Regions of the World: A Review Article. Open AIDS J. 2018;12:81-92. doi: http://dx.doi.org/10.2174/1874613601812010081 39. Sousa KAA, Araújo TME, Teles SA, Rangel EML, Nery IS. Factors associated with HIV prevalence in a prison population. Rev Esc Enferm USP. 2017;51:e03274. doi: http://dx.doi.org/10.1590/S1980-220X2016040903274 40. Sá GGM, Silva FL, Santos AMR, Nolêto JS, Gouveia MTO, Nogueira LT. Technologies that promote health education for the community elderly: integrative review. Rev. Latino-Am. Enfermagem. 2019;27:e3186. doi: http://dx.doi.org/10.1590/1518-8345.3171.3186

41. Williams AM, Gift TL, O'Donnell LN, Rietmeijer $C A$, Malotte $C K$, Margolis AD, et al. Assessment of the
Cost-Effectiveness of a Brief Video Intervention for Sexually Transmitted Disease Prevention. Sex Transm Dis. 2020;47(2):130-5. doi: http://dx.doi.org/10.1097/ OLQ.0000000000001109

42. Gurgel SS, Taveira GP, Matias EO, Pinheiro PNC, Vieira NFC; Lima FET. Educational games: didactic resources utilized at teaching health education classes. Rev Min Enferm. 2017;21:e-1016. doi: http://dx.doi. org/10.5935/1415-2762.20170026

43. Hightow-Weidman LB, Muessig KE, Bauermeister JA, LeGrand S, Fiellin LE. The future of digital games for HIV prevention and care. Curr Opin HIV AIDS. 2017;12(5):501-7. doi: http://dx.doi.org/10.1097/ $\mathrm{COH} .0000000000000399$

44. Stoltzfus JR, Libarkin J. Does the Room Matter? Active Learning in Traditional and Enhanced Lecture Spaces. CBE Life Sci Educ. 2016;15(68):1-10. doi: http://dx.doi.org/10.1187/cbe.16-03-0126

45.Theobald EJ, Hill MJ, Tran E, Agrawal S, Arroyo EN, Behling $S$, et al. Active learning narrows achievement gaps for underrepresented students in undergraduate science, technology, engineering, and math. Proc Natl Acad Sci U S A. 2020;117(12):6476-83. doi: http:// dx.doi.org/10.1073/pnas.1916903117
Received: Apr 6 2020 Accepted: Jul $15^{\text {th }} 2020$

Associate editor:

Maria Lúcia Zanetti

Copyright $\odot 2020$ Revista Latino-Americana de Enfermagem This is an Open Access article distributed under the terms of the Creative Commons (CC BY).

This license lets others distribute, remix, tweak, and build upon your work, even commercially, as long as they credit you for the original creation. This is the most accommodating of licenses offered. Recommended for maximum dissemination and use of licensed materials. 